\title{
Sea-Level Rise and the Law of the Sea in the Western Pacific Region
}

\section{Nguyen Hong Thao*}

\begin{abstract}
Sea-level rise (SLR) is considered one of the most serious consequences of climate change. The risk of SLR compels legal consideration of this phenomenon related to many interrelated domains including the Law of the Sea. The Western Pacific region contains the most low-lying coastal countries and small island States seriously affected by SLR in the world. This research has been carried out as a contribution paper on the State practice in the Western Pacific region to the topic of "Sea-level rise in relation to international law" conducted by the Study Group of the United Nations International Law Commission in the period of 2020-2021. It aims to summarize the consequences of SLR for the Western Pacific States and outline their legal positions in relation to the sea-level rise. It also discusses specific issues, challenges and opportunities facing the Western Pacific States in supporting the maintenance of maritime baselines and limits notwithstanding physical changes caused by SLR.
\end{abstract}

\section{Keywords}

Sea Level Rise, Law of the Sea, Western Pacific, Baseline Limit, Low-lying Coastal Countries, Small Island States, UNCLOS

* Vice Chairman of the United Nations International Law Commission; Associated Professor of Diplomatic Academy of Vietnam; Vietnamese Arbitrator under Article 2 of Annes VII to UNCLOS. A.B. (Navy College of Bacu, ex-USSR). LL.M./Ph.D.(Paris I-Panteon-Sorbonne). The author may be contacted at: thaonguyenhong57@gmail.com/Address: 69 Chua Lang Str. Hanoi, Vietnam.

All the websites cited in this article were last visited on May 6, 2020. 


\section{Introduction}

Sea-level rise ("SLR") is considered one of the most serious consequences of climate change ${ }^{1}$ that will occur in the twenty-first century or even beyond $2100{ }^{2}$ It heavily affects the global economy, environment, security and order at sea. ${ }^{3}$ The risk of SLR compels legal consideration of this phenomenon related to the Law of the Sea, International Law on Statehood, Environmental Law, Human Right Law, Migration Law and others. It has gradually been clarified by studies of the International Law Association ("ILA"), " the UN International Law Commission ("ILC") ${ }^{5}$ and other researchers. Most of them confirm that the main legal implications of SLR concern the Law of the Sea, in particular, maritime baselines and limits. At a regional level, the Western Pacific region contains the most low-lying and small island States seriously affected by SLR in the world.

This research aims to summarize the consequences of SLR for the Western Pacific States and outline their legal positions in relation to this phenomenon. This paper consists of four parts including Introduction and Conclusion. Part two will focus on the impact of SLR and the response of States in the region. Part three will discuss the legal basis of maintaining maritime baselines and boundaries notwithstanding physical changes caused by SLR.

1 SLR is estimated in the range of $0.84 \mathrm{~m}$ (0.61-1.10 m, likely range) by 2100. See IPCC, 2019: SUMmARY FOR Policymakers-Special Report on the Ocean and Cryosphere in a Changing Climate B.3.1, 23 (H.-O. Pörtner, et al. eds. 2019), available at https:/www.ipcc.ch/site/assets/uploads/sites/3/2019/11/SROCC_FinalDraft_FullReport.pdf.

2 IPCC, AR5 Synthesis Report: Climate Change, IPCC.CH (2014), available at https://www.ipcc.ch/report/ar5/syr.

3 R. Nicholls, 'Case study on sea-level rise impacts,' OECD Workshop on the Benefits of Climate Policy: Improving Information for Policy Makers (2003). See M. Hayashi, Sea Level Rise and the Law of the Sea: How can the Affected States be Better Protected?, in The Limits of Maritime Jurisdiction 609-25 (2014); Y. Takamura, Climate Change and Small Island Claims in the Pacific, in Climate Change: International Law and Global Governance 1. 657-83 (O. Ruppel et al. eds., 2013).

4 D. Vidas, D. Freestone, \& J. McAdam, International Law and Sea Level Rise: Report of the International Law Association Committee on International Law and Sea Level Rise (2019), available at https://www.researchgate.net/ publication/330938568_International_Law_and_Sea_Level_Rise_Report_of_the_International_Law_Association Committee_on_International_Law_and_Sea_Level_Rise.

5 ILC, Commentary to Draft Article 3 of the "Protection of Persons in the event of Disasters" Report (Report on the work of the sixty-eight session), U.N. Doc. A/71/10 (2016), 23, ๆ 4; "Sea-level rise in relation to international law" (Report on the work of the seventh session), U.N. Doc. A/73/10 (2018), ๆ 152; G.A. Res. 73/265 (Dec. 22, 2018). 


\section{Sea-Level Rise and Actions of the Western Pacific States}

The Western Pacific region comprises of twenty-six States and territories from Asia and twenty-seven from Oceania. ${ }^{6}$ SLR varies in size in different maritime zones, from coastal, offshore, semi-enclosed seas to the ocean. Depending on their geographical profiles in relation to SLR, countries in the Western Pacific can be classified into four groups: Small Island Developing States (“SIDS”), low-lying coastal countries, big archipelagic States, and remaining States.

SIDS are mainly made up of coral reefs, who are small in size and scattered over a large surface with a total of 2.7 million inhabitants. ${ }^{7}$ They are poor economies and five are officially classified as Least Developed Countries ("LDCs") (Kiribati, Tuvalu, Solomon Islands, Timor Lester and Vanuatu). Most of islands are low, flat and located in the ocean. Scientific data shows the trend of SLR in some SIDS such as the Cook Islands (+2.5 mm/year), Samoa (+6.9), Tonga (+8.0); Tuvalu (+6.4), Fiji (+2.5), Kiribati (+5.7), Marshall Islands (+5.2), Vanuatu (+3.1), Nauru (+7.1), Solomon Islands, $(+6.8)$ and Papua New Guinee $(+8.1){ }^{8}$ Considering their predicted SLR by 2100 , this group faces a host of threats: shifting baselines and limits, losing statehood, and increasing the SLR migration. These new risks prompt this group to take fast political and legal initiatives to address climate change, including SLR, at the national and regional levels.

Tonga is the first island country in the Western Pacific region to develop the Joint Action Plan on climate change and disaster risk management in 2010. ${ }^{9}$ The policies of SIDS focus on: disaster displacement; ${ }^{10}$ information about future threats; building flood barriers, levees, dikes and seawalls; and relocating facilities and people to higher elevations. ${ }^{11}$ However, they have rapidly found that geoengineering solutions,

6 See Asia-Pacific countries in 2019, WorLd POPULATION Rev., available at http://worldpopulationreview.com/countries/ apac-countries. The APAC region is made up of a collection of countries located in or near the Western Pacific Ocean, throughout East and South Asia, Southeast Asia and Oceania.

7 International Union for Conservation of Nature, Oceania (2019), available at https://www.iucn.org/commissions/ commission-ecosystem-management/regions/oceania.

8 Australian Government Bureau of Meteorology, South Pacific Sea Level and Climate Monitoring Project: Sea Level Data Summary Report (Nov. 2005 to June 2006), at 27 (Table 2), available at http://www.bom.gov.au/ntc/IDO60102/ IDO60102.2006_1.pdf.

9 Tonga Joint National Action Plan 2 on Climate Change and Disaster Risk Management 2018-2028, available at https:// www.pacificclimatechange.net/sites/default/files/documents/JNAP\%20II\%20-\%202018-2028.pdf.

10 Vanuatu National Disaster Management Office, Vanuatu National Policy on Climate Change and Disaster-Induced Displacement, available at https://www.iom.int/sites/default/files/press_release/file/iom-vanuatu-policy-climatechange-disaster-induced-displacement-2018.pdf.

11 N. Dauenhauer, On the front line of climate change as Maldives fights rising seas, NEw ScIENTIST, Mar. 20, 2017, 
including land reclamation work to consolidate the existing basepoints, are one, albeit not the best, option for poor and vulnerable States whose economic and technical capacities are limited.

Since 2011, Pacific Island Countries ("PIC") have applied a new strategy to improve their legal position in response to the impact of SLR. They have accelerated their progress in officially notifying lists of geographical coordinates of their claims to maritime baselines and zones. In 2013, Tuvalu deposited five Declarations on baselines and archipelagic baselines, on outer limits of territorial sea, economic exclusive zones ("EEZ") and a continental shelf to the UN Secretariat. ${ }^{12}$ In 2016, the Marshall Islands issued a Declaration to change from the normal baseline method to straight baselines determined by reference to geographical coordinates of points. ${ }^{13}$

The idea of maintaining the defined baselines and maritime zones appeared not only in individual State proclamations and actions. In their continuous public statements, PIC have also recalled the "legal recognition of the defined baselines established under the United Nations Convention on the Law of the Sea [UNCLOS] to remain in perpetuity irrespective of the impacts of sea level rise." ${ }^{\text {"14 }}$ The Fiftieth Pacific Islands Forum ("PIF") in 2019 encouraged Members to conclude all outstanding maritime boundary claims and zones. Leaders of the PIF committed to a collective effort, including the development of international law, with the aim of ensuring that once a Forum Member's maritime zones are delineated in accordance with the UNCLOS, the Member's maritime zones cannot be challenged or reduced as

available at https://www.newscientist.com/article/2125198-on-front-line-of-climate-change-as-maldives-fights-risingseas/\#ixzz5uoE61Nwk.

12 Tuvalu Declaration on Territorial Sea Baselines 2012, Declaration of Archipelagic Baselines 2012, Declaration of the Outer Limits of the Territorial Sea 2012, Declaration of the Outer Limits of the Exclusive Economic Zones 2012, Declaration of the Outer Limits of the Continental Shelf 2012, available at https://www.un.org/Depts/los/ LEGISLATIONANDTREATIES/STATEFILES/TUV.htm.

13 Marshall Islands, Declaration of Baselines \& Maritime Zones Outer Limits and its Schedule (Apr. 18 2016), available at https://www.un.org/Depts/los/LEGISLATIONANDTREATIES/PDFFILES/DEPOSIT/mhl_mzn120_2016_2.pdf; Marine Zones (Declaration) Act 1984 (An Act to make provisions in respect of the Internal Waters, the Archipelagic Waters, the Territorial Sea, the Exclusive Economic Zone and the Contiguous Zone of the Republic), available at https://www.un.org/Depts/los/LEGISLATIONANDTREATIES/PDFFILES/MHL_1984_Act.pdf.

14 DELAP Commitment, Securing Our Common Wealth of Oceans - Reshaping the Future to Take Control of the Fisheries, 8 (Mar. 2, 2018), available at http://www.pnatuna.com/sites/default/files/Delap\%20Commitment_2nd\%20 PNA\%20Leaders\%20Summit.pdf. See also C. Pratt \& H. Govan, Our Seas of Islands, Our Livelihoods, Our OceaniaFramework for a Pacific Oceanscape: A Catalyst for Implementation of Ocean Policy 32 (2010), available at https://www. forumsec.org/wp-content/uploads/2018/03/Framework-for-a-Pacific-Oceanscape-2010.pdf; Palau Declaration on "The Ocean: Life and Future," annex B (2014), available at http://www.forumsec.org/wp-content/uploads/2017/11/2014Palau-Declaration-on-\%E2\%80\%98The-Ocean-Life-and-Future\%E2\%80\%99.pdf; PIF, 49th Pacific Islands Forum Communique, ๆๆ 26-27 (2018), available at https://uploads.guim.co.uk/2018/09/05/1FINAL_49PIFLM Communique_for_unofficial_release_rev.pdf. 
a result of SLR and climate change. ${ }^{15}$ In a short period (2011-14), with the assistance of Australian experts, fourteen maritime boundary agreements were formally endorsed, compared with only two during the period between 2002 and 2010. ${ }^{16}$ As of 2019, thirty-four out of forty-eight overlapping or shared EEZs in this region have been successfully settled. It is understandable that PIF countries encourage a three-step policy to cope with SLR: 1) fix and deposit geographical coordinates of maritime baselines and limits; 2) conclude outstanding maritime boundaries as soon as possible; and 3) maintain in perpetuity baselines and maritime boundaries delineated in accordance with the UNCLOS notwithstanding SLR. ${ }^{17}$

The second group comprises some countries having low-lying coastal areas, including Krishna and Brahmani (India), Ganges-Brahmaputra (Bangladesh), Mekong (Vietnam) deltas and some areas from China, Thailand and others. In this group, Vietnam and Bangladesh are in the top five countries most impacted by SLR in the world. Between 2011 and 2016, Vietnam built three scenarios in the face of SLR (Low 49-64cm, Medium 57-73, and High 78-95cm). ${ }^{18}$ Up to 10 percent of its area (330, $000 \mathrm{~km}^{2}$ ) would be affected by a $1 \mathrm{~m}$ SLR and 16 percent by a $5 \mathrm{~m}$ SLR by 2100.10 .8 percent of Vietnam's population would be impacted by a 1m SLR. The measures to respond to climate change, including SLR focus on: 1) Assessing and forecasting the impact and vulnerability of populations to SLR; 2) Developing a master plan for socio-economic development to adapt to climate change; 3) Developing protection measures for islands to cope with climate change, particularly SLR; 4) Developing spatial planning and technical infrastructure for residential areas to cope with climate change; and 5) Assessing and developing livelihoods and production processes to cope with climate change and SLR. ${ }^{19}$ The adaptation to SLR is a target of the new

15 PIF, 50th Pacific Islands Forum Communiqué, ๆণ 25-26 (Aug. 16, 2019), available at https://www.forumsec.org/ wp-content/uploads/2019/08/50th-Pacific-Islands-Forum-Communique.pdf.

16 Geoscience Division, Pacific Maritime Boundaries Project, Pacgeo.org (2017), available at http://www.pacgeo.org/ static/maritimeboundaries.

17 Submission of the Federated States of Micronesia, forwarded through Verbal Note FSMUN 058-2019 and Submission of the Members of the Pacific Islands Forum to the International Law Commission on the Topic of Sea-Level Rise in relation to International Law, Dec. 27, 2019. See PIF, Leaders Meeting Communiqué (Aug. 16, 2019), available at https://www.forumsec.org/fiftieth-pacific-islands-forum-tuvalu-13-16-august-2019; Palau Declaration on the Ocean: Life and Future (Aug. 1, 2014), available at http://www.forumsec.org/wp-content/uploads/2017/11/2014-PalauDeclaration-on-'The-Ocean-Life-and-Future'.pdf.

18 T. Thuc et al., Climate Change and Sea Level Rise Scenarios for Viet Nam (2016), available at https://www. researchgate.net/publication/318875854_Climate_Change_and_Sea_Level_Rise_Scenarios_for_Viet_Nam_Summary_for_Policymakers/link/5a3cadbaa6fdcc21d878b167/download.

19 Socialist Republic of Vietnam, Vietnam National Climate Change Strategy (NCCS), Chinhphu.vn (2011), available at http://www.chinhphu.vn/portal/page/portal/English/strategies/strategiesdetails?categoryId=30\&artic leId=10051283. See also Vietnam Ministry of Natural Resources and Environment, Climate Change and Sea LeVel Rise Scenarios For VIETNAm 15 (2009), available at https://www.preventionweb.net/files/11348_Climate 
strategy for sustainable development of the Vietnamese marine economy up to 2030, with a vision toward $2045 .^{20}$ Measures to adapt and mitigate climate change, including the impact of SLR, are identified as building quays, ports and store houses or creating transitional belts between land and sea by building back-up dikes behind sea dikes. ${ }^{21}$ Vietnam submitted lists of geographical coordinates of their straight baselines in $1982^{22}$ and the joint submission of outer limits of continental shelf with Malaysia as well as its partial submission in $2009 .{ }^{23}$ It has three maritime boundaries concluded with Thailand in 1997, ${ }^{24}$ with China in the Tonkin Gulf in 2000, ${ }^{25}$ and with Indonesia in $2003{ }^{26}$ Like other Asian States, ${ }^{27}$ Vietnam has no statement on the possibility of changing baselines in adapting to SLR."

Bangladesh has a $710 \mathrm{~km}$-long coast along the Bay of Bengal, with 46 million people living in coastal areas of $47,201 \mathrm{~km}^{2}$ that are at risk from SLR. It will lose 17.5 percent of its land $\left(25,000 \mathrm{~km}^{2}\right)$ with a SRL of $1 \mathrm{~m}$ by $2100 .{ }^{28}$ Sundarbans and part of the Barguna Patuakhali coastal zones with a length of $226 \mathrm{~km}$ are highly vulnerable. ${ }^{29}$ SLR in the Bay of Bengal is estimated to be $10 \mathrm{~mm} /$ year, the world's highest. ${ }^{30}$ The

\section{ChangeSeaLevelScenariosforVi.pdf.}

20 Socialist Republic of Vietnam, Strategy for Sustainable Development of the Vietnamese Marine Economy up to 2030, with A Vision toward 2045, VGP NEws, Jan. 30, 2019, available at http://news.chinhphu.vn/Home/Partys-Resolutionon-strategy-for-sustainable-development-of-marine-economy/20191/35784.vgp.

21 P. Gass, H. Hove \& J. Parry, Review of Current and Planned Adaptation Action: East and Southeast Asia (2011), available at https://www.iisd.org/project/review-current-and-planned-adaptation-action-developing-countriessupporting-adaptation.

22 Statement of November 12, 1982 by the Government of the Socialist Republic of Viet Nam on the Territorial Sea Baseline of Viet Nam, available at https:/www.un.org/Depts/los/LEGISLATIONANDTREATIES/PDFFILES/ VNM_1982_Statement.pdf.

23 Vietnam-Malaysia Joint Submission to the Commission on the Limits of the Continental Shelf pursuant to Article 76, paragraph 8 of UNCLOS 1982 in respect to the southern part of the South China Sea (May 2009), available at https:// www.un.org/Depts/los/clcs_new/submissions_files/mysvnm33_09/mys_vnm2009excutivesummary.pdf.

24 N. Thao, Vietnam's First Maritime Boundary Agreement, IBRU Boundary SEC. Bull. 74-8 (1997).

25 H. Nguyen, Maritime Delimitation and Fishery Cooperation in the Tonkin Gulf, 36 OCEAN Dev. \& InT'L L. 25-45 (2005).

26 Vietnam-Indonesia Agreement on Delimitation of Continental Shelf (2003), available at https://www.un.org/Depts/los/ LEGISLATIONANDTREATIES/STATEFILES/VNM.htm.

27 ASEAN, Joint Communiqué of the 52nd ASEAN Foreign Ministers' Meeting Bangkok (July 31, 2019), available at https://asean.org/storage/2019/07/CIRCULATE-Joint-Communique-of-the-52nd-AMM-FINAL.pdf.

28 G. Sarwar \& M. Khan, Sea Level Rise a Threat to the Coast of Bangladesh, 38 InT'L Q. Asian Stud. 375-397(2007). See also Water Resources Planning Organization, Coastal Development Strategy (2006), available at http://old.warpo. gov.bd/strategy/coastalDevPolicy.pdf.

29 G. Sarwar, Sea-Level Rise along the Coast of Bangladesh, in Disaster Risk Reduction Approaches In Bangladesh 227 (R. Shaw, F. Mallick, \& A. Islam eds. 2013).

30 Bangladeshi Ministry of Environment and Forests Department of Environment, Climate Change Cell, Assessment of Sea Level Rise on Bangladesh Coast through Trend Analysis, (2016), at 23. See J. Ericson et al., Effective Sea-level Rise and Deltas: Causes of Change and Human Dimension Implications, 50(1) Global Planetary Change 63-82 (2006). 
Bangladeshi Government launched its National Adaptation Programme of Action ("NAPA") in 2005 and its Climate Change Strategy and Action Plan 2009 for a 10-year's programme until 2018 to meet the challenge of climate change, including SLR. ${ }^{31}$ In November 2015, Bangladesh amended straight baselines declared in 1974 in order to reduce the length of straight baselines, but not in response to the impact of SLR. $^{32}$

The relative SLR rate in various Chinese coastal areas is in the range of 5-9 mm/ year. This indicates that it may reach some $30-50 \mathrm{~cm}$ in the coastal areas by 2050, and in a few areas such as the Old Yellow River Delta it will be $70 \mathrm{~cm}^{33} 78$ million Chinese citizens live in low-elevation cities. ${ }^{34}$ In 2014, China launched Sponge Cities projects. ${ }^{35}$ China declared the straight baselines of territorial sea in 1996 and added a new declaration of baselines adjacent to Diaoyu Dao and its affiliated islands on September 10, 2012. ${ }^{36}$ Both are fixed by geographical coordinates unchangeable by the impact of SLR.

With at least 30 percent of land area $\left(700 \mathrm{~km}^{2}\right)$ less than $5 \mathrm{~m}$ above sea level, Singapore pushes up land reclamation work instead of adjusting baselines and maritime limits (25\% added to its land area). Singapore needs USD 100 billion or more over the long-term to combat rising sea levels. ${ }^{37}$ In brief, this group focuses more on geoengineering measures than the policy of adaptation and mitigation regarding the impact of SLR. They do not have any statement on changing baselines in response of the impact of SLR.

The Western Pacific has the two biggest archipelagic States-the third group under analysis. One is Indonesia who is an archipelagic State composed from 17.504 islands

31 See Bangladesh Climate Change Strategy and Action Plan 2009, available at https://www.iucn.org/downloads/ bangladesh_climate_change_strategy_and_action_plan_2009.pdf.

32 Baseline, Territorial Sea and Exclusive Economic Zone of People's Republic of Bangladesh, S.R.O. No. 328Law/2015/MOFA/UNCLOS/113/2/15, dated Nov. 4, 2015 with a list of geographical coordinates of points concerning the straight baselines for measuring the breadth of the territorial sea of Bangladesh, available at https://www.un.org/ Depts/los/LEGISLATIONANDTREATIES/PDFFILES/DEPOSIT/bgd_mzn118.pdf.

33 J. Chen, The Impact of Sea Level Rise on China's Coastal Areas and Its Disaster Hazard Evaluation. 13(3) J. CoASTAL REs. 929 (1997).

34 World Bank, Cities and Climate Change: An Urgent Agenda, Vol. 10 (Dec. 2010), available at http://siteresources. worldbank.org/INTUWM/Resources/340232-1205330656272/CitiesandClimateChange.pdf.

35 C. Zevenbergen, D. Fu and A. Pathirana, Transitioning to Sponge Cities: Challenges and Opportunities to Address Urban Water Problems in China, 10(9) WATER (2018), available at https://www.mdpi.com/2073-4441/10/9/1230.

36 Statement of the Government of the People's Republic of China on the straight baselines of territorial sea adjacent to Diaoyu Dao and its affiliated islands (Sept. 10, 2012), available at https://www.un.org/Depts/los/LEGISLATION ANDTREATIES/PDFFILES/DEPOSIT/chn_mzn89_2012_e.pdf.

37 Lee Hsien Loong, Prime Minister, Singapore, PM Loong Speech on National Day Rally 2019 (Aug. 18, 2019), available at https://www.pmo.gov.sg/Newsroom/National-Day-Rally-2019. 
and $108.000 \mathrm{~km}$ coastline. ${ }^{38} 98.4$ percent of Indonesia population lives within $100 \mathrm{~km}$ of the coast. The sea level in Indonesia has increased by $1-8 \mathrm{~mm}$ per year depending on places. ${ }^{39}$ In an extreme scenario, it could rise from $0.98 \mathrm{~m}$ to 1.18 by the year of $2100 .^{40}$ The North of the Java and Sumatra coasts (Indonesia) are most vulnerable by SLR and flooding. In 2019, Indonesia decided on the relocation of the capital city from Jakarta to the island of Kalimantan due to floods. ${ }^{41}$ The construction of a new capital is starting from 2020. ${ }^{42}$ Indonesia's archipelagic baseline system, set forth in Regulation No. 37 of 2008, is composed of 192 baseline segments, of which 160 are straight archipelagic baselines and thirty-two are normal baseline segments. ${ }^{43}$ The basepoints are on islands not on any low-tide elevation. Indonesia has numerous maritime boundary negotiations. It has nineteen maritime boundary-related agreements with neighboring countries. The Indonesia Climate Change Roadmap of 2009 and the National Climate Change Action Plan of 2007 have no provisions on the change of status of the archipelagic baselines and maritime boundaries under the impact of SLR.

The other is the Philippines. The Philippines' National Framework Strategy on Climate Change 2010-2022 predicted 129,114 ha of land lost from a $1 \mathrm{~m} \mathrm{SLR}{ }^{44}$ The archipelagic baselines and territorial sea of the Philippines have been defined and amended through the Republic Act No. 3046 of June 17, 1961, the Republic Act No. 5446 of 1968 and the Republic Act No. 9522 of 2009. The latest revision has 101 line segments, ranging in length from $0.08 \mathrm{~nm}$ (segment 99-100) to $122.88 \mathrm{~nm}$ (segment 46-47), with a total length of 2,808 $\mathrm{nm} .{ }^{45}$ The archipelagic straight baselines joined

38 R. Mardhiah, The Impact of Sea Level Rise on Indonesia's Maritime Zones, slide presentation at the Roundtable on Sea-level Rise and the Law of the Sea with Members of the International Law Commission (Nov. 14-15, 2019).

39 ADB, The Economics of Climate Change in Southeast Asia: A Regional Review 68 (2009), available at https://www. adb.org/sites/default/files/publication/29657/economics-climate-change-se-asia.pdf.

40 H. Förster et al., Sea-level rise in Indonesia: On Adaptation Priorities in the Agricultural Sector, 11(4) REG'L ENVTL. ChAnge 893-904 (2010), available at https://www.researchgate.net/publication/233728224_Sea-level_rise_in Indonesia_On_adaptation_priorities_in_the_agricultural_sector.

41 V. Cordoba, Jokowi urges citizens to agree on moving Indonesian capital to Kalimantan, INDEPENDENT, Aug. 16, 2019, available at $\mathrm{http}: / /$ theindependent.sg/jokowi-urges-citizens-to-agree-on-moving-indonesian-capital-to-kalimantan.

42 J. Massola \& K. Rompies, Jakarta Sinks as Indonesian Capital and Borneo Takes on Mantle, Sydney MornING Herald, Aug. 26, 2019, available at https://www.smh.com.au/world/asia/jakarta-sinks-as-indonesian-capital-andborneo-takes-on-mantle-20190826-p52kvp.html.

43 US Department of State Bureau of Oceans and International Environmental and Scientific Affairs, Indonesia: Archipelagic and other Maritime Claims and Boundaries, 141 Limits of the Sea (2014), available at https://2009-2017. state.gov/documents/organization/231912.pdf.

44 Climate Change Commission, National Framework Strategy on Climate Change 2010-2022 (2010), at 10, available at http:/www.neda.gov.ph/wp-content/uploads/2013/10/nfscc_sgd.pdf.

45 US Department of State Bureau of Oceans and International Environmental and Scientific Affairs, Philippines: Archipelagic and other Maritime Claims and Boundaries, 142 Limits of the Sea (2014), available at https:/www.state. 
the outermost points of the outermost islands and drying reefs of the archipelago. No low-tide elevation is used to draw the baselines. This revision aims to exclude Scarborough Reef and the Kalayaan Island Group from the archipelagic baseline system for political and legal reasons not due to the impact of SLR.

It seems that archipelagic States have not wanted to change archipelagic baselines, which rely on high islands and drying reefs, in response to the impact of SLR. Indonesia and the Philippines, in their new declarations on their archipelagic baselines notified the permanent geographical coordinates of straight archipelagic baselines. $^{46}$

The remaining countries in the Western Pacific region belong to the fourth group, comprising of States with a range of concerns regarding SLR-from landlocked States such as Laos and Mongolia to rich and not seriously affected countries such as Australia, New Zealand or South Korea. ${ }^{47}$ Almost all countries in the Western Pacific region have approved their own national strategies on mitigation and adaptation in response to climate change, including SLR. The 2008 Australian plan focuses on coastal embankment projects, setback provisions, retreat and/or abandonment of vulnerable areas. ${ }^{48}$ The Australian Seas and Submerged Lands (Territorial Sea Baseline) Proclamation 2016 is not intended to effect any substantive changes to the baselines defined in the previous proclamation. ${ }^{49}$

In Asia, maritime delimitation settlement is slower. Since 2000, seven maritime

gov/wp-content/uploads/2019/10/LIS-142.pdf.

46 The list of geographical coordinates of points of the Indonesian archipelagic baselines based on the Government Regulation of the Republic of Indonesia number 38 as of 2002 as amended by the Government Regulation of the Republic of Indonesia, No. 37 (2008), available at https:/www.un.org/Depts/los/LEGISLATIONANDTREATIES/ PDFFILES/DEPOSIT/idn_mzn67_2009.pdf. See also The list of geographical coordinates of points as contained in Republic Act No. 9522: An Act to Amend Certain Provisions of Republic Act No. 3046, as Amended by Republic Act No. 5446, to Define the Archipelagic Baselines of the Philippines, and for Other Purposes, Maritime Zone Notifications M.Z.N. 69. 2009. LOS (Apr. 21, 2009), available at https://www.un.org/Depts/los/LEGISLATIONANDTREATIES/ PDFFILES/phl_2008_act9522.pdf.

47 New Zealand Ministry for the Environment, Adapting to Sea-Level Rise (Dec. 12, 2017), available at https:/www. mfe.govt.nz/climate-change/climate-change-and-government/adapting-climate-change/adapting-sea-level-rise. Sealevels in New Zealand rose on average by $1.7 \mathrm{~mm}$ per year from 1900 to 2008. See also P. Watson, Updated Mean SeaLevel Analysis: South Korea, 35 J. CoAstal Res. 241-50 (Mar. 1, 2019); D. Kim et al., Sea Level Rise and Storm Surge around the Southeastern Coast of Korea, Special Issue, 79 J. COASTAL Res. 239-43 (2007).

48 N. Gurran et al., Planning for climate change adaptation in Coastal Australia: State of practice, Report No. 4 for the National Sea Change Taskforce 1-83 (Nov. 2011), available at https://www.aph.gov.au/DocumentStore. ashx?id=f3395f51-b8a5-4e55-af57-85189e6e2da0. See also Antarctic Climate \& Ecosystems Cooperative Research Centre, Position Analysis: Climate Change, Sea-Level Rise and Extreme Events: Impacts and Adaptation Issues 15-7 (2008), available at http://www.cmar.csiro.au/sealevel/downloads/SLR_PA.pdf.

49 Australian Government, Seas and Submerged Lands (Territorial Sea Baseline) Proclamation 2016, § 7 (Baselinemainland of Australia), available at https:/www.legislation.gov.au/Details/F2016L00302/Explanatory\%20Statement/ Text. 
disputes have been successfully completed. ${ }^{50}$ All of them were concluded without taking SLR into account. In some cases, there was no mention of how maritime baselines impact on the settled line because they were reached on the basis of the equitable principle. Most of them do not have the terminal provision on the review or termination of maritime agreement. ${ }^{51}$

The Western Pacific region has made twenty-four submissions, including three joint submissions, on the outer limit of the continental shelf to the Commission of the Limits of the Continental Shelf ("CLCS"). 52 To date, however, there is only one recommendation, adopted by the Commission in $2012 .^{53}$

In the region, some cases that the International Court of Justice ("ICJ") principally engages with are on sovereign disputes rather than maritime disputes. ${ }^{54}$ The Timor Sea Conciliation case between Timor-Leste and Australia in $2018^{55}$ did not mention the impact of SLR on maritime delimitation. The Permanent Court of Arbitration ("PCA") in Bangladesh $v$. India rejected climate change as a factor in maritime delimitation by noting that: "[i]n the view of the Tribunal, neither the prospect of climate change nor its possible effects can jeopardize the large number of settled maritime boundaries throughout the world. This applies equally to maritime boundaries agreed between States and to those established through international adjudication." 56 This conclusion excludes the issue of the future instability of the coastline caused by SLR or other

50 China-Viet Nam on the maritime delimitation in Bac Bo Gulf (2000); Yemen-Saudi Arabia (2000); OmanPakistan, (2000); Oman-Yemen (2003); Indonesia-Singapore in the western part of the Strait of Singapore (2009); Saudi Arabia-Jordan in the Gulf of Aqaba (2007); Iran-Oman (2015), available at https://www.un.org/Depts/los/ LEGISLATIONANDTREATIES/STATEFILES.

51 The 1995 Agreement between the Government of Malaysia and the Government of the Republic of Singapore to delimit precisely the territorial waters boundary in accordance with the Straits Settlements and Johore Territorial Waters Agreement 1927, art. 2.

52 Submission to the CLCS (Australia-2004; Bangladesh-2011; China in part of the East China Sea-2012, Cook Islands-2009; Fiji-2009; India-2009; Indonesia-2008; Japan-2008; Kiribati-2012; Malaysia and Vietnam-2009; Maldives-2010; Federated States of Micronesia, Papua New Guinea and the Solomon Islands-2009; Myanmar-2008; New Dilan-2006 and Joint submission with Tuvalu and France 2012; Pakistan-2009; Palau-2009; Philippines-2009; Republic of Korea-2012; Sri Lanka-2009; Tonga-2009; Vietnam-2009; Yemen-2009, available at https://www.un.org/ Depts/los/clcs_new/commission_submissions.htm.

53 CLCS, Recommendations of the Commission on the Limits of the Continental Shelf in Regard to the Submission made by the Philippines in Respect of the Benham Rise Region (Apr. 8, 2009), available at https://www.un.org/depts/los/ clcs_new/submissions_files/phl22_09/phl_rec.pdf.

54 Sovereignty over Pulau Ligitan and Pulau Sipadan (Indon. v. Malay.), Judgment, 2002 I.C.J. Rep. (Dec. 17); Sovereignty over Pedra Branca/Pulau Batu Puteh, Middle Rocks and South Ledge (Malay. vs. Sing.), Judgment, 2008 I.C.J. Rep. (May 23).

55 Timor Sea Conciliation (Timor-Leste v. Austl.), Compulsory Conciliation Commission Report and Recommendations (2018).

56 The Bay of Bengal Maritime Boundary Arbitration (Bangl. v. India), 1217 (Perm. Ct. Arb., 2014), available at https:// pca-cpa.org/en/news/bay-of-bengal-maritime-boundary-arbitration-between-bangladesh-and-india-bangladesh-v-india. 
natural phenomenon on existing maritime boundaries. In the South China Sea Arbitration, the PCA provided that geological or geomorphological criteria are not relevant in assessing the legal status of a particular high-tide feature. ${ }^{57}$ Consequently, States with insular features that sustain human habitation in historical use may be able to maintain claims from those features affected by SLR.

The foregoing survey prompts some initial remarks. First, due to the different geographical profiles and the impact of SLR, each group of States undertakes its own response to SLR. Concern with SLR is not unique to the region. However, the subsequent practice of the Western Pacific States can evidence their understanding of the object and purpose of the UNCLOS, ${ }^{58}$ which is to preserve legal stability and security regardless the impact of SLR. Second, States tend to use the straight baseline rather than normal in the context of SLR. Third, States in the region share a view on the permanency of maritime boundaries. Fourth, the initiative of PIF States supported by the acts or omissions of other States should be a starting point to find an aceptable solution, based on consistent practice, for when the existing legal system does not explicitly deal with the impact of SLR on maritime baselines and limits.

\section{Legal Base for Maintaining Maritime Baselines and Boundaries in the Face of SLR}

Any proposal or solution addressing SLR must fulfill the object and purpose of the UNCLOS: "the strengthening of peace, security, cooperation and friendly relations among all nations in conformity with the principles of justice and equal rights and will promote the economic and social advancement of all peoples of the world, in accordance with the Purposes and Principles of the United Nations as set forth in the Charter." ${ }^{59}$ It must minimize the changes to the existing Law of the Sea. In this Part, the debate will concentrate on the specific issues, challenges and opportunities facing the Western Pacific States in supporting the maintenance of maritime baselines and limits.

57 The South China Sea Arbitration (Phil. v. P.R.C.), $\uparrow 950$ \& 548 (Perm. Ct. Arb., 2016). See also S. Kaye, The Law of the Sea Convention and Sea Level Rise after the South China Sea Arbitration, 93 InT'L L. Stud. 443 (2017); C. Schofield \& D. Freestone, Islands Awash Amidst Rising Seas: Sea Level Rise and Insular Status under the Law of the Sea, 34 Int'L. J. Marine \& Coastal L. 413 (2019).

58 Subsequent agreements and subsequent practice in relation to the interpretation of treaties, I.L.C. Report, Seventieth session (2018), U.N. Doc. A/73/10, ch. IV, Conclusion 3 and Commentary, at 23-25, available at http://legal.un.org/ docs/?path=.//ilc/reports/2018/english/chp4.pdf\&lang=EFSRAC.

59 UNCLOS, pmbl., available at https://www.un.org/depts/los/convention_agreements/texts/unclos/unclos_e.pdf. 


\section{A. Interpretation of the UNCLOS}

The establishment of legal order at sea and of maritime zones defined from baselines is the greatest success of the UNCLOS. Baselines (normal in Article 5; straight in Article 7; and archipelagic in Article 47 of the UNCLOS) can have at least three functions. The first function is to serve as a starting point to extend the territorial sea, outer limit of the continental shelf, outer limit scope of all maritime economic exclusive zone, and the outer limit of a continental shelf ${ }^{60}$ The second function of baselines is navigational safety. The third function is the role of the baseline in setting up maritime delimitation and conducting international relations at sea. SLR threatens to change the configuration of coasts, and, consequently, baselines.

Truly reflecting the configuration of the coast, normal baseline allows coastal States to gain territory in the event of alluvion or losing land in case of regression of the low-water line. The normal baseline is ambulatory when the sea moves landward or seaward. Reflecting the general direction of the coast, the straight baseline is less ambulatory than the normal one. This method is applied only in three exceptional localities where the coastline is deeply indented and cut into, or if there is a fringe of islands along the coast in its immediate vicinity, or in the case of the presence of highly unstable coastlines such as deltas and other natural conditions. Archipelagic baselines are straight. SLR can make some basepoints disappear so that the conditions, which determined the ratio of the area of water to the area of land and depart from the original configuration of the archipelago, ${ }^{61}$ would be reconsiderable. Indeed, Article $7(2)$ of the UNCLOS is the only regulation that provides a "pemanent character" to straight baselines regarding highly unstable delta. ${ }^{62}$ When the Convention does not give an exact meaning of the term "highly unstable" and the time limit for redrafting straight baselines, Article 7(2) can be applied as a stable solution for almost every delta in the world. ${ }^{63}$ Low-lying coastal States can employ this article to maintain straight baselines without taking impact brought by SLR. SIDS, whose land are mostly coral islands and cays, cannot rely on this article. They follow a trend of replacing normal baselines with the application of straight baselines. ${ }^{64}$ Article $7(3)$

UNCLOS, art. 76(6), available at https://www.un.org/depts/los/convention_agreements/texts/unclos/unclos_e.pdf.

$61 \quad$ Id. art.47 (2), (3) \& (4).

62 Article 7(2) of the UNCLOS provides: “... notwithstanding subsequent regression of the low-water line, the straight baselines shall remain effective until changed by the coastal State in accordance with this Convention."

63 G. Andreone (ed.), The Future of the Law of the Sea, Bridging Gaps Between National, Individual and Common Interests 7 (2017). See also S. Busch, Sea Level Rise and Shifting Maritime Limits: Stable Baselines as a Response to Unstable Coastlines, 9 Arctic Rev. L. Pol. 188 (2018).

64 V. Prescott \& C. Schofield, The Maritime Political Boundaries of the World 163 (2005). See also supra note 4, $\uparrow$ 100. The ILA observes that a majority of coastal States ( 90 of 150) have sought to proclaim straight baselines relying 
can be invoked to maintain straight baseline because the sea areas lying within the current straight baseline and configuration of the coast deformed by SLR are "sufficiently closely linked to the land domain to be subject to the regime of internal waters." ${ }^{65}$ This area would become territorial sea while the baseline shifts landward but it continues to enjoy the legal status of internal waters obtained at the moment of baseline declaration. A flexible interpretation of the UNCLOS's provisions can justify the approach of maintaining straight baselines but not for normal baselines.

The ambulatory nature of baselines leads to ambulatory changes to the limits of claimed maritime zones. In this regard, Article 76(9) reconfirms the permanency of the outer limit of continental shelf. ${ }^{66}$ Furthermore, this permanency is confirmed by the certainty of the boundary of the area needed to ensure the interests and benefits of the international community as well as investors in the seabed. ${ }^{67}$ Maintaining maritime limits, except the outer limit of continental shelves beyond $200 \mathrm{~nm}$, is only based on the argument to respect peace and stability at the sea, as proclaimed in the preamble to the UNCLOS.

Coastal States have an obligation to give due publicity to large scale charts and lists of geographical coordinates of baselines determined in accordance with Articles 7, 9 and 10, or of the limits derived therefrom, and the lines of delimitation drawn in accordance with Articles 12, 15, 74 and 83 of the UNCLOS. A copy of each such chart or list shall be deposited with the UN Secretary-General. ${ }^{68}$ This obligation applies more so to straight lines. However, the UNCLOS does not clarify whether the deposit of charts or lists of geographical coordinates ensures the permanency of those baselines and limits. Baseline renewal is open. In practice, Bangladesh, the Philippines and some other countries redraw their respective baselines for reasons other than SLR. Therefore, if States postpone updating their charts in response to the impact of SLR, current straight baselines and limits would be maintained.

\section{B. Fundamental Change of Circumstances}

The ambulatory nature of baselines can prompt the question of the validity of maritime boundaries concluded or adjudicated with those lines. In other words, the concern is whether SLR can be qualified as a "fundamental change of circumstances" for re-concluding maritime agreements. Not all maritime limits function to delineate

on Article 7 of the UNCLOS.

65 UNCLOS art. 7(3).

66 Id. art. 76(9).

67 Id. art. 76(8).

68 Id. arts. 16,47 (9), 75 \& 84. 
sovereignty as a territorial boundary, but the term 'boundary' may broadly be interpreted to include the various lines which fix the spatial limits of different powers, such as the limits of territorial seas, continental shelves and EEZs. ${ }^{69}$ Therefore, Article 62.2 (a) of the 1969 Vienna Convention on the Law of Treaties referring to the status of boundary can apply for maritime limits. They permanently exist having legal effect in international relations notwithstanding any "fundamental change of circumstances." Jurisprudence reconfirms the permanent character of maritime boundaries in a number of instances. ${ }^{71}$ Scholarly writings support views on the applicability of Article 62 to treaties on maritime limits beyond territorial seas. ${ }^{72}$ In its 2018 Report, the ILA gave a clear statement that "although changes in coasts and baselines brought about by sea level rise or any other reason may have affected a boundary in some way, they had not to date affected the validity of an existing maritime boundary agreement." This approach is relevant for the stability of both the UNCLOS and the Vienna Convention on the Law of Treaties.

Maintaining the validity of an existing maritime boundary agreement in relation to SLR can be justified for the following reasons. First, delimitation of an EEZ or continental shelf, in accordance with Articles 74 and 83 of the UNCLOS, shall be carried out on the basis of the equitable, not the equidistance, principle. Under the equitable principle SLR must be considered to equally impact on both concerned parties. SLR is not accepted as a special circumstance which creates an advantage for one party and a detriment for another. The equitable principle is understood as a win-win solution whereby any potential change, including the recession of coastal configuration due to SLR, must be considered to equally influence both sides of the dispute. Moreover, one coastal State can involve two or more maritime delimitation cases; in one case, it could gain, while, in the other case, it could lose maritime areas due to the impact of SLR. The State cannot be free to claim the beneficial impact of SLR in one case and reject detrimental impacts in another. Moreover, a study

69 Report of the International Law Commission to the General Assembly on the work of the 34th session, U.N. Doc. A/37/10, reprinted in [1982] 2 Y.B. Int'1 L. Comm'n 59-61, available at http://legal.un.org/docs/?path=../ilc/ documentation/english/reports/a_37_10.pdf\&lang=EFSXP.

70 Vienna Convention on the Law of Treaties, art. 62, available at http://legal.un.org/ilc/texts/instruments/english/ conventions/1_1_1969.pdf.

71 Bay of Bengal Maritime Boundary Arbitration (Bangl. v. India), 63, ศฯ 216-217 (Perm. Ct. Arb. 2014). See also Aegean Sea Continental Shelf (Greece v. Turk.), Judgment, 1978 I.C.J. Rep. 36-37, ๆ 85 (Dec. 19).

72 D. Caron, When Law Makes Climate Change Worse: Rethinking the Law of Baselines in Light of a Rising Sea Level, 17(4) Ecology L. Q. 653 (1990). See also C. Schofield, Holding back the waves? Sea level rise and Maritime Claims, in Climate Change: International Law and Global Governance: Legal Responses and Global Responsibility 609 (O. Ruppel et al. eds., 2013).

73 Supra note 4 , at 21. 
showed that only one third of maritime cases took account of maritime baselines in delimitation. ${ }^{74}$ The solution of keeping all maritime limits as they are, regardless of SLR, would be fair in both State practice and jurisprudence.

Second, SLR is not a "fundamental change of circumstances." In fact, the change of sea level is a normal phenomenon when the UNCLOS accepts the term "lowwater and high-water marks" in some provisions to define maritime baselines and features. As part of climate change, SLR is an induced human phenomenon, not purely natural. The States most vulnerable to SLR are developing countries, which have the right to require compensation from developed countries and emerging economies responsible for global warming because of their 'contribution' of CO2 to atmosphere. ${ }^{75}$ SIDS and low-lying coastal States can invoke the principle of "common but differentiated responsibilities" to require special treatment to combat the impact of SLR. Maintaining agreed maritime limits also reflects the recent trend of the Western Pacific coastal countries doing so. A large number of maritime delimitation agreements concluded recently in this region indicate that concerned States have not considered warnings about SLR constituting a fundamental change of circumstances.

Third, the typically long process of negotiation provides an opportunity to take account of possible SLR. The maritime delimitation in the Gulf of Tonkin, for example, took 30 years (1974-2004) to conclude. ${ }^{76}$ The risk is that a new revision would take an equal or greater amount of time, while the final solution does not guarantee the stability and spirit of cooperation between the concerned States. Keeping fixed maritime limits may apply equally to maritime boundaries delimited by decisions of international courts or arbitral tribunals. It creates favorable conditions for the negotiation of new multilateral agreements such as the future agreement under the UNCLOS on the conservation and sustainable use of marine biological diversity of areas beyond national jurisdiction. The scope of application of new international agreements will be based on the unchangeable of current maritime boundaries and outer limits of maritime areas under national jurisdiction. ${ }^{77}$ Maintaining existing maritime boundary agreements avoids conflicts over the exploration and exploitation

74 A. Soons, The Effects of a Rising Sea Level on Maritime Limits and Boundaries, 37 Neth. InT'L L. Rev. 207-32 (1990).

75 ILC Draft Articles on Responsibility of States for International Wrongful Acts, art. 47, available at https://legal.un.org/ ilc/texts/instruments/english/draft_articles/9_6_2001.pdf. See H. Ralston, B. Horstmann, \& C. Holl, Climate Change challenges Tuvalu, Germanwatch 15-6 (2004); G. Xue, Climate Change Challenges and the Law of the Sea Responses, in Climate change: International LaW and Global Governance 572 (O. Ruppel et al. eds., 2013).

76 Supra note at 25. See also Z. Keyuan, Maritime Boundary Delimitation in the Gulf of Tonkin, 30 OcEan Dev. \& InT'L L. 235-54 (1999).

77 Draft text of an agreement under the UNCLOS on the conservation and sustainable use of marine biological diversity of areas beyond national jurisdiction, 3rd session, New York, Aug. 19-30, 2019, note by the President, U.N. Doc. A/ CONF.232/2019/6, available at $\mathrm{https://papersmart.unmeetings.org/media2/21996841/note-by-the-president-draft-text.pdf.}$ 
of natural resources at sea. It thereby contributes to the maintenance of international peace, security and stability of international legal order at sea. It is obvious that SLR cannot constitute a fundamental change of circumstances in relation to the maintenance of maritime baselines and limits. Maritime boundaries are changed through the mutual agreement of concerned States.

\section{The Land Dominates the Sea Principle}

Some scholars criticize that the ambulatory nature of baselines as an example of "the land dominates the sea" ("LDS") principle. ${ }^{78}$ Others indicate that the principle has not been mentioned in the UNCLOS. The principle has been considered a pragmatic tool used by judges in maritime delimitation and not necessarily relevant to SLR. ${ }^{79}$ This interpretation is more rigid. It is evident that the LDS principle has not appeared in the texts of the global ocean law treaties such as the 1958 Geneva Conventions on the Law of the Sea or the UNCLOS. In the judgment of North Sea Continental Shelf case in $1969,{ }^{80}$ the ICJ addressed this principle, but its spirit appeared before ${ }^{81}$ and in subsequent works of international courts and tribunals. ${ }^{82}$ However, it does not mean that the LDS principle has its origins in jurisprudence. The ICJ only identified that pre-existing State power at sea derives from the land. ${ }^{83}$ It indicated that the starting point for any maritime entitlement extends from the coast. This principle has been crystalized through Mare clausum by John Selden in the 17th century, the Truman Proclamation on the continental shelf in 1945, the Kenyan initiative on 200nm EEZ in 1972 and so on. The LDS principle has traces in almost all articles of the UNCLOS. Article 2 allows for coastal States to extend "beyond its land territory and internal

78 S. Busch, Sea Level Rise and Shifting Maritime Limits: Stable Baselines as a Response to Unstable Coastlines, 9 Arctic Rev. L. \& Pol. 174-6 (2018).

79 Supra note 4 (Report of the Committee on Baselines under the International Law of the Sea, 2018), at 16.

80 North Sea Continental Shelf Case (F.R.G. v. Denmark. Neth.), Judgment, 1969 I.C.J. Rep. 32, 43 (Feb. 20).

81 Grisbadarna Case (Nor. v. Swed.), Arbitral Award, Permanent Court of Arbitration 4 (Perm. Ct. Arb. 1909). It provides: "maritime territory is an essential appurtenance of land territory." See also Bing Bing Jia, The Principle of the Domination of the Land over the Sea: A Historical Perspective on the Adaptability of the Law of the Sea to New Challenges, 57 German Y.B INT'L L. 7 (2014), available at http:/www.iilj.org/wp-content/uploads/2016/09/ JiaIILJColloq2015.pdf; Fisheries Case (U.K. v. Nor.), Judgment, 1951 I.C.J. Rep. 133 (Dec. 18). It provides: "It is the land which confers upon the coastal State a right to the waters off its coasts."

82 Aegean Sea Continental Shelf (Greece v. Turk.), Judgment, 1978 I.C.J. Rep. 36, 96 (Dec. 19); Continental Shelf (Tunis. v. Libya), Judgment, 1982 I.C.J. Rep. 61, ๆ 73 (Feb. 24); Maritime Delimitation and Territorial Questions between Qatar and Bahrain (Qatar v. Bahr.), Judgment, 2001 I.C.J. Rep. 40, ๆ 185 (July 1); Maritime Delimitation in the Black Sea (Rom. v. Ukr.), Judgment, 2009 I.C.J. Rep. 61, ๆ 77 (Feb. 3).

83 North Sea Continental Shelf Case, supra note 80, at 51, ๆ 96. For details, see D. Caron, Climate Change, Sea Level Rise and the Coming Uncertainty in Oceanic Boundaries: A Proposal to Avoid Conflict, in Maritime Boundary Disputes, Settlement Processes, and the Law of the Sea 14 (S.-Y. Hong \& J. Van Dyke, eds., 2009). 
waters and, in the case of an archipelagic State, its archipelagic waters, to an adjacent belt of sea, described as the territorial sea, sovereignty of a coastal State." ${ }^{84}$ The land confers upon the coastal State a right of up to $200 \mathrm{~nm} \mathrm{EEZ}{ }^{85}$ and a continental self even beyond 200nm from the baseline. ${ }^{86}$ The scope of applying the LDS principle coves all maritime zones adjacent to the coast and extends to the outer limit of the continental shelf of coastal States. The application of the principle is expressed in the provisions of treaties, bilateral and multilateral, in jurisprudence, in unilateral declarations and so on. State practice in this application is general, expressive, or creative. The UNCLOS also deals with the principle. Not only the LDS principle but Articles 5 and 7 of the UNCLOS that link with low water line imply also the static and ambulatory natures of baselines.

The 'Land,' including islands and rocks, must be "naturally formed" elevated above the sea level, ${ }^{88}$ not depending on any geological or geomorphological criteria. ${ }^{89}$ The LDS principle allows for excluding all artificial constructions to extend maritime entitlement, but it does not refuse the measures for artificial protection of basepoints in response to SLR. It is evident that the "Land dominates" closely links with a State's sovereignty. The terre nullius is incapable of generating maritime zones. The 'Land' under the sovereignty of a coastal State allows for generating maritime zones by the intermediary of the coastal front, ${ }^{90}$ regardless of the inhabitable character $^{91}$ or size of the land behind the coast. It means that even if a part of the 'Land,' whose sovereignty has been defined, becomes inhabitable due to SLR, it continues to have the capacity to generate maritime zones. ${ }^{92}$ Land domination gives legal possession of adjacent maritime zones as well as of their resources to coastal States. This permanent character is confirmed by the UN General Assembly Resolutions in 1962, 1972 and $1973 .^{93}$ The ICJ also found it in Maritime Delimitation in

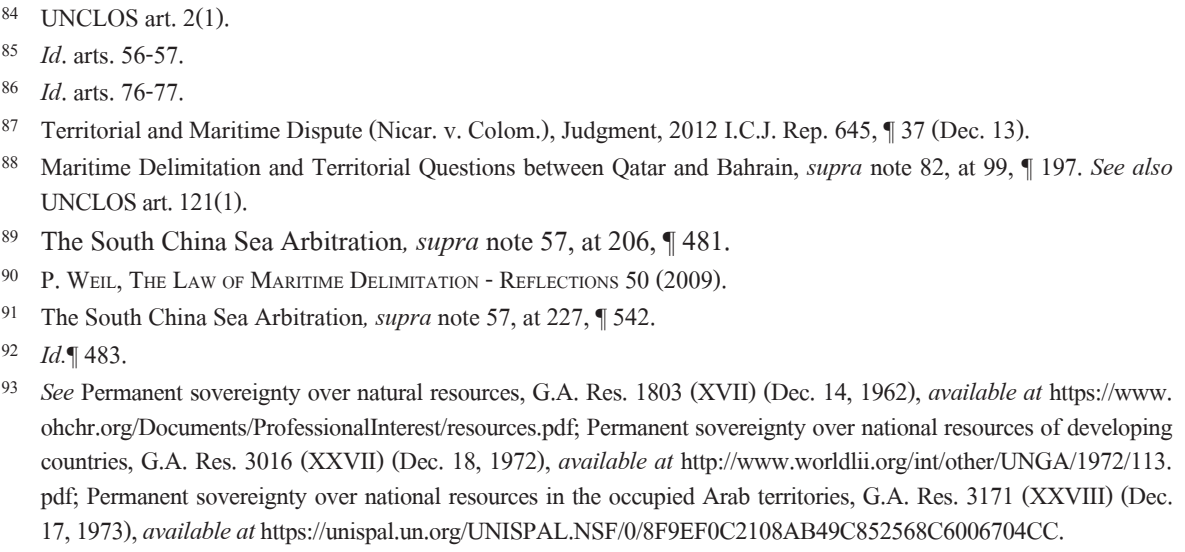
ohchr.org/Documents/ProfessionalInterest/resources.pdf; Permanent sovereignty over national resources of developing countries, G.A. Res. 3016 (XXVII) (Dec. 18, 1972), available at http://www.worldlii.org/int/other/UNGA/1972/113. pdf; Permanent sovereignty over national resources in the occupied Arab territories, G.A. Res. 3171 (XXVIII) (Dec. 17, 1973), available at https://unispal.un.org/UNISPAL.NSF/0/8F9EF0C2108AB49C852568C6006704CC. 
the Area between Greenland and Jan Mayen case. ${ }^{94}$ The inclusion of the word 'permanent' indicates that land domination is not a specific principle for maritime delimitation. It is a general principle creating the maritime entitlement of a coastal State at sea. This capacity disappears only in the case where the total mainland territory under State sovereignty is lost (No Land, No Sea). SIDS States can apply the flexible interpretation of the UNCLOS complemented by the static aspect of the LDS principle to maintain their maritime baselines and limits until their islands and reefs disappear totally and completely.

The moments when States were recognized as having rights over maritime areas are different. The sovereign rights of coastal State over the continental shelf, originating from the natural prolongation of its land territory to the outer edge of the continental margin, exist naturally from the moment of the formation of the State. ${ }^{95}$ They are inherent, ${ }^{96}$ not depending on occupation, effective or notional, or on any express proclamation. ${ }^{97}$ On the contrary, the limits of territorial sea, EEZs and continental shelf up to $200 \mathrm{~nm}$ and their respective competences have been formed by the State's declaration on its baseline and breadth of those maritime zones measured from it. ${ }^{98}$ Legally speaking, the moment when the land dominates the sea is when the declaration of the baseline for the measurement of the breadth of territorial sea was generally recognized by the international community, except for the case of identifying the outer limits of the continental shelf. States are reluctant to accept losing land due to the impact of SLR in redrawing baselines. Unless the territorial land disappears totally and baselines are redrawn, the permanency of the LDS principle is even more important. First, it gives a coastal State an entitlement to extend the competence from existing land to the sea. Second, it permanently freezes this fixed entitlement at the moment of maritime delimitation. This competence continues existing regardless of the changes in coasts because the recently submerged land has originated from the land determined at the moment of concluding the agreement. In other words, a flexible interpretation of the LDS principle can be applied to justify the maintenance of maritime baselines and limits defined in accordance with the UNCLOS. What are not regulated by this Convention continue to be governed by the

94 Maritime Delimitation in the Area between Greenland and Jan Mayen (Den. v Nor.), Judgment, 1993 I.C.J. Rep. 74, 9 80 (June 14). See also I. Papanicolopulu, The Land Dominates The Sea (Dominates The Land Dominates The Sea), 47 Questions INT'L L. 39 (2018).

95 UNCLOS art. 76.1.

96 North Sea Continental Shelf Case, supra note 80, at 22, \ 19.

97 UNCLOS art. 77.3.

98 D. Vidas, Sea-Level Rise and International Law: At the Convergence of Two Epochs, 4 Climate L. 74 (2014). 
rules and principles of general international law. ${ }^{99}$ The LDS principle thus does not go against the maintenance of maritime baseline and limits.

\section{Regular Review}

When coastal configuration changes caused by SLR, the baselines should be reviewed and redrew for the navigational safety. Articles 5, 7 and 47 of the UNCLOS as well as the LDS principle reflect the two different aspects: static and dynamic. Regular review is not required explicitly in the UNCLOS texts, while reviews of straight baselines are required in cases of highly unstable delta. ${ }^{100}$ It can be understood that whenever baseline changes, the coastal State shall give due publicity to charts or lists of geographical coordinates of new baseline and shall deposit a copy of each such chart or list with the UN Secretary-General. Changes to coastal configurations may be caused by other factors aside from SLR. Therefore, this obligation is not fulfilled only one time. When baseline moves landward, the legal status of water area located between the current baseline and new configuration of the coastline deformed by SLR will be changed from status of internal waters to the status of territorial sea. Consequently, some parts of current territorial sea will be put under the legal status of exclusive economic zone and so on. Maintaining current baselines in that case implies to increase internal waters of coastal States, while the freedoms of sea and innocent passage of other States will not be moved landward respectively. By contrast, the immediate and continuous revision of maritime baselines and limits will seriously affect international order at sea which is thereby contrary to the object and purposes of the UNCLOS, i.e., "the strengthening of peace, security, cooperation and friendly relations among all nations." ${ }^{, 101}$ Regular review requires substantial time and resources to determine new baselines and negotiate new maritime limits. It is not pragmatic but would impose a significant administrative and engineering burden on small and developing States. ${ }^{102}$ In practice, there are only two cases of regular review. The first is Finland which reviewed straight baseline every 30 years. ${ }^{103}$ The second is the Interagency Committee on the Delimitation of the US Baseline which has the function of reviewing and approving any changes to the US baselines other than de

\footnotetext{
9 UNCLOS pmbl.

100 UNCLOS arts. 7(2), 16, 75 \& 84.

101 Id.

102 PIF, Leaders Meeting, Communiqué (Aug. 16, 2019), available at https://www.forumsec.org/fiftieth-pacific-islandsforum-tuvalu-13-16-august-2019.

103 Prescott, supra note 64, at 161.
} 
minimis ones (i.e. shifts that are greater than 500 meters). ${ }^{104}$

The existing law of the sea system must be interpreted flexibly to balance the two interrelated poles. The Resolution of the ILA in 2018 endorsed the idea that "baselines and limits should not be required to be recalculated should sea level change affect the geographical reality of the coastline." ${ }^{105}$ This idea is based on the grounds of legal certainty and stability, provided that the baselines and the outer limits of maritime zones of a coastal or an archipelagic State have been properly determined by the UNCLOS. This recommendation is encouraged because it meets the willingness of vulnerable States to maintain the baselines and limits of their current maritime zones established in accordance with the Convention, notwithstanding physical coastline changes caused by SLR. It reinforces the emergence of State practice, particularly in the Western Pacific region to maintain those maritime baselines and limits. It prevents the risk of extravagant spending to build artificial constructions ${ }^{106}$ and the possibility of extreme land reclamation work ${ }^{107}$ for the protection of coastlines and features from SLR and erosion. The "maintenance of existing entitlements" to maritime zones facilitates the minimum change to the existing law of the sea possible. It will be appropriate until 2100 with the mark chosen by IPCC reports. Beyond then, if the national identity of a small island States have the potential to disappear totally and completely, however, the question of reviewing maritime baselines and limits would be raised. The argument to maintain baselines and maritime limits, as fixed in accordance with the UNCLOS and the coordinates and charts deposited with the UN Secretary-General, is strong now but will not be forever. Over time, maintaining navigational safety by updating the actual recession of the coastline could become a concern to keep in mind. Future assessments should foresee a longer-term solution. The current interpretation of the UNCLOS should be changed to reflect the reality of maritime geography after a sufficiently long term period. It will depend on States' decisions. State Parties to the UNCLOS can call a conference to examine this issue. In

104 C. Symmons \& M. Reed, Baseline Publicity and Charting Requirements: An Overlooked Issue in the UN Convention on the Law of the Sea, 41 OCEAN DEv. \& INT'L L. 77-111 (2010).

105 Res. 5/2018 of the Committee on International law and Sea level Rise at the 78th Conference of the International Law Association, held in Sydney, Australia (Aug. 19-24, 2018), available at http://www.ila-hq.org/images/ILA/Resolutions/ ILAResolution_5_2018_SeaLevelRise.pdf.

106 Japanese attempt to save Okinotorishima rocks that elevate no more than two feet out of above water at high tide. See S.-Y. Hong, Okinotorishima: A "rock" or an "island"? Recent maritime boundary controversy between Japan and Taiwan/China', in Maritime Boundary Disputes, Settlement Processes, and the Law of the Sea 145-76 (J. Van Dyke ed., 2009); Japan's submission to the Commission on the limits of the continental shelf pursuant to art. 76 para. 8 of the UNCLOS, Executive Summary (2008), available at http://www.un.org/Depts/los/clcs_new/submissions_files/jpn08/ jpn_execsum-mary.pdf.

107 I. Overland, Impact of Climate Change on ASEAN International Affairs Risk and Opportunity Multiplier 6, available at https:/www.researchgate.net/publication/320622312. 
awaiting a new decision, the maintenance of maritime baselines and limits remains the best option.

\section{Conclusion}

In order to safeguard peace, stability, international order at sea and to avoid conflicts, the Western Pacific States, through their general practice, acts or omission, have coherently adopted a unique attitude towards SLR: maintaining maritime baselines and limits established in accordance with the UNCLOS, regardless of the impact of SLR. This stance has been based on the object and purpose of the UNCLOS to preserve peace, security, stability and certainty. However, it is not suitable to codify this stance. A flexible interpretation of the UNCLOS and the LDS principle can be applied instead at the moment. However, State practice is further necessary to conclude on the possible emergence of a customary rule of international law in this regard. It depends on the coherent practice of vulnerable States, the support and tolerance of other States, the international community, and the flexible interpretation of existing law.

The UNCLOS is accepted in "package deal," aiming to balance the interests of all members of the Convention. In the extreme case that SLR is enough great to question Statehood, other States and the international community have the right to request the review of baselines in some parts of the world beyond 2100. A final solution needs to be considered by an international conference. The "Fixed baselines and maritime limits concluded in accordance with UNCLOS maintain their validity when the land exists (or until the land disappears) regardless of the impact of SLR except as otherwise agreed by international community" could become a rule established through reference to the Western Pacific State practices, with the support or acquiescence of the other States. This guarantees fairness to all countries and the international community if global warming continues. This rule saves the time for States to find more effective measures and solutions to control greenhouse gas emission and to adapt to SLR. This option also preserves the existing law of the sea. Simultaneously, it opens the door for advancing the rule of law over the seas and oceans in the future to adapt to the challenges posed by SLR. In conclusion, I would like to borrow the words of David D. Caron: "As we have come to realize that our assumption regarding the constancy of nature was simplistic, and inasmuch as nature 
142 Nguyen Hong Thao

declines to negotiate, it is we and our laws which must adapt."108

Received: February 1, 2020

Modified: March 30, 2020

Accepted: May 15, 2020

108 D. Caron, When Law Makes Climate Change Worse: Rethinking the Law of Baselines in Light of a Rising Sea Level, 17 Ecology L. Q. 653 (1990). 